\title{
COMMENTARY
}

\section{New conclusive data on human myocardial dysfunction induced by acidosis}

\author{
Antoine Kimmoun $n^{1,2,3}$, Nicolas Ducrocq ${ }^{1,2,3}$ and Bruno Levy ${ }^{* 1,2,3}$ \\ See related research by Schotola et al., http://ccforum.com/content/16/4/R153/abstract
}

\begin{abstract}
Acidosis is one of the major consequences of hemodynamic instability in shock state patients directly associated with multiple organ failure evolution and death. Most studies on the hemodynamic consequences of acidosis have been experimental, nonhuman studies with severe acidosis, and thus far from the most common clinical situations. Schotola and colleagues offer a new approach to human failing myocardium where the authors highlight, ex vivo, the deleterious hemodynamic consequences of mild acidosis. Their work strengthens the current view of the urgent need to discover new efficient and nondeleterious therapy for the treatment of acidosis.
\end{abstract}

During the shock state, understanding the mechanisms of acidosis, its hemodynamic and inflammatory consequences as well as the best therapeutic approach remain an ongoing debate. In the previous issue, Schotola and colleagues provide, for the first time, new and enlightening data on the consequence of acidosis in isolated human failing myocardium [1].

Over the past two decades, the mortality rate from a shock state has decreased; for instance, in septic shock from $30 \%$ to around $20 \%$ [2,3]. This improvement stems from many factors, including early management, more aggressive resuscitation with specific goals (volemic expansion, targeted main arterial pressure, blood transfusion, and so forth) and a better identification of prognostic factors such as acidosis [4]. As a major metabolic consequence of shock states, acidosis is also known to be a high predictor of in-hospital mortality [5]. Both a cause and a consequence, this acidosis impairs cardiac and

*Correspondence: b.levy@chu-nancy.fr

'INSERM, Groupe Choc, contrat Avenir INSERM, U961, Faculté de Médecine,

54511 Vandoeuvre les Nancy, France

Full list of author information is available at the end of the article vascular function through various cellular and molecular mechanisms. Intracellular acidosis, which reduces myofilament sensitivity to $\mathrm{Ca}^{2+}$, is thus one of the crucial factors involved in myocardial dysfunction [6]. A low $\mathrm{pH}$ value also induces vessel hyporeactivity mediated by a number of factors such as nitric oxide, peroxynitrite, activation of $\mathrm{K}_{\mathrm{ATP}}$ channels and modification of catecholamine signaling [7].

Although it has long been known that cardiovascular function is impaired by acidosis, the bulk of the studies have been mostly experimental, and only a few human studies have been relevant on this subject [8-10]. In the present study by Schotola and colleagues, the authors obtained ventricular trabeculae from human right ventricles explanted from failing hearts. These trabeculae were mounted in a chamber in which the development of isometric force was recorded and the tissues superfused with a HEPES solution at pH 7.20 and 7.40. The response to incremental doses of isoproterenol, a B mimetic agent, was also recorded. Their major finding was a reduction in cardiac contractility at $\mathrm{pH} 7.20$ and a rightward shift of the $\mathrm{pH} 7.20$ curve compared with the 7.40 curve in response to increasing doses of isoproterenol. Therefore, without providing actual new pathophysiological information regarding cardiac depression in acidotic patients, this study definitely confirms the deleterious effects of a moderate and common acidosis on the failing human heart. Obviously, these experimental conditions (that is, ex vivo fragments of myocardium, artificial organic acidosis) are far from the clinical situation. However, this study confirms all other previous results. Furthermore, given that the hemodynamic consequences of common mild acidosis on altered myocardium are important, physicians should be alarmed in the presence of severe acidosis. In shock patients, hemodynamic treatment in order to treat acidosis should be a primary goal for the physician. Finally, it would be of interest, albeit ethically complex, to determine whether this mild acidosis has the same impact not only on preserved human myocardium but also on both preserved and altered arterial vessels.

The management of acidosis remains a complex challenge. The main treatment must involve the correction of the 
underlying disease at the origin of acidosis. However, buffering severe acidosis by sodium bicarbonate is known to be associated with severe deleterious effects. One such effect is paradoxical intracellular acidosis. Bollaert and colleagues demonstrated that sodium bicarbonate infusion in acidotic rats decreases the intracellular $\mathrm{pH}$ [11]. Moreover, sodium bicarbonate infusion increases carbon dioxide, which is highly diffusible in cells $\left(\mathrm{HCO}_{3}{ }^{-}\right.$ $+\mathrm{H}^{+}<=>\mathrm{H}_{2} \mathrm{CO}_{3}$ and $\left.\mathrm{H}_{2} \mathrm{CO}_{3}<=>\mathrm{CO}_{2}+\mathrm{H}_{2} \mathrm{O}\right)$. Carbon dioxide increases dramatically and exacerbates cardiovascular dysfunction [12]. Another deleterious effect is that hypocalcemia is worsened by bicarbonate infusion, which probably also impairs cardiovascular function [9]. A final example is hydric and sodium overload, which often occurs during sodium bicarbonate infusion.

Two small randomized, controlled clinical studies describe the inefficiency of this treatment in restoring the hemodynamic balance in critically ill patients $[9,10]$. Other treatments such as Carbicarb, an equimolar solution of sodium bicarbonate and sodium carbonate, or THAM (trometamol; tris-hydroxymethyl aminomethane), a biologically inert amino alcohol of low toxicity that buffers carbon dioxide and acids in vitro and in vivo, have also been studied for the treatment of metabolic or respiratory acidosis, although not in shock state patients $[8,13]$.

For all of these reasons, bicarbonate therapy is not recommended even with $\mathrm{pH}<7.15$. In fact, the Surviving Sepsis Campaign guidelines only recommend against its use for $\mathrm{pH} \geq 7.15$ [4]. Currently, there are no relevant published studies regarding the effect of bicarbonate therapy for $\mathrm{pH}<7.15$. Nevertheless, while the underlying disease remains the main course of treatment, there is an urgent need to research a new symptomatic approach to acidosis management.

\section{Competing interests}

The authors declare that they have no competing interests.

\section{Author details}

'INSERM, Groupe Choc, contrat Avenir INSERM, U961, Faculté de Médecine 54511 Vandoeuvre les Nancy, France. ${ }^{2} \mathrm{CHU}$ Nancy, Service de Réanimation Médicale Brabois, Pole Cardiovasculaire et Réanimation Médicale, Hôpital Brabois, 54511 Vandoeuvre les Nancy, France. ${ }^{3}$ Université de Lorraine, 54000 Nancy, France.

Published: 28 September 2012
References

1. Schotola H, Toischer K, Popov AF, Renner A, Schmitto JD, Gummert J, Quintel M, Bauer M, Maier LS, Sossalla S: Mild metabolic acidosis impairs the betaadrenergic response in isolated human failing myocardium. Crit Care 2012, 16:R153

2. Bernard GR, Vincent JL, Laterre PF, LaRosa SP, Dhainaut JF, Lopez-Rodriguez A, Steingrub JS, Garber GE, Helterbrand JD, Ely EW, Fisher CJ Jr; Recombinant human protein C Worldwide Evaluation in Severe Sepsis (PROWESS) study group: Efficacy and safety of recombinant human activated protein $\mathrm{C}$ for severe sepsis. N Engl J Med 2001, 344:699-709.

3. Ranieri VM, Thompson BT, Barie PS, Dhainaut JF, Douglas IS, Finfer S, Gardlund B, Marshall JC, Rhodes A, Artigas A, Payen D, Tenhunen J, Al-Khalidi HR, Thompson V, Janes J, Macias WL, Vangerow B, Williams MD, Group P-SS: Drotrecogin alfa (activated) in adults with septic shock. N Engl J Med 2012, 366:2055-2064.

4. Dellinger RP, Levy MM, Carlet JM, Bion J, Parker MM, Jaeschke R, Reinhart K, Angus DC, Brun-Buisson C, Beale R, Calandra T, Dhainaut JF, Gerlach H, Harvey M, Marini JJ, Marshall J, Ranieri M, Ramsay G, Sevransky J, Thompson BT, Townsend S, Vender JS, Zimmerman JL, Vincent JL, et al: Surviving Sepsis Campaign: international guidelines for management of severe sepsis and septic shock: 2008. Crit Care Med 2008, 36:296-327.

5. Lee SW, Hong YS, Park DW, Choi SH, Moon SW, Park JS, Kim JY, Baek KJ: Lactic acidosis not hyperlactatemia as a predictor of in hospital mortality in septic emergency patients. Emerg Med J 2008, 25:659-665.

6. Liou YM, Chang JC: Differential pH effect on calcium-induced conformational changes of cardiac troponin C complexed with cardiac and fast skeletal isoforms of troponin I and troponin T. J Biochem 2004, 136:683-692.

7. Levy B, Collin S, Sennoun N, Ducrocq N, Kimmoun A, Asfar P, Perez P, Meziani $\mathrm{F}$ : Vascular hyporesponsiveness to vasopressors in septic shock: from bench to bedside. Intensive Care Med 2010, 36:2019-2029.

8. Leung JM, Landow L, Franks M, Soja-Strzepa D, Heard SO, Arieff Al, Mangano DT: Safety and efficacy of intravenous Carbicarb in patients undergoing surgery: comparison with sodium bicarbonate in the treatment of mild metabolic acidosis. SPI Research Group. Study of Perioperative Ischemia. Crit Care Med 1994, 22:1540-1549.

9. Cooper DJ, Walley KR, Wiggs BR, Russell JA: Bicarbonate does not improve hemodynamics in critically ill patients who have lactic acidosis. A prospective, controlled clinical study. Ann Intern Med 1990, 112:492-498.

10. Mathieu D, Neviere R, Billard V, Fleyfel M, Wattel F: Effects of bicarbonate therapy on hemodynamics and tissue oxygenation in patients with lactic acidosis: a prospective, controlled clinical study. Crit Care Med 1991, 19:1352-1356.

11. Bollaert PE, Robin-Lherbier B, Mallie JP, Nace L, Escanye JM, Larcan A: Effects of sodium bicarbonate on striated muscle metabolism and intracellular pH during endotoxic shock. Shock 1994, 1:196-200.

12. Berger DS, Fellner SK, Robinson KA, Vlasica K, Godoy IE, Shroff SG: Disparate effects of three types of extracellular acidosis on left ventricular function. Am J Physiol 1999, 276(2 Pt 2):H582-H594.

13. Nahas GG, Sutin KM, Fermon C, Streat $S$, Wiklund $L$, Wahlander $S$, Yellin $P$, Brasch H, Kanchuger M, Capan L, Manne J, Helwig H, Gaab M, Pfenninger E, Wetterberg T, Holmdahl M, Turndorf H: Guidelines for the treatment of acidaemia with THAM. Drugs 1998, 55:191-224.

doi:10.1186/cc11520

Cite this article as: Kimmoun A, et al.: New conclusive data on human myocardial dysfunction induced by acidosis. Critical Care 2012, 16:160. 